\title{
Integrated Management of Tomato Spotted Wilt on Field-Grown Tomatoes
}

\author{
M. T. Momol, Plant Pathology Department, S. M. Olson, Horticultural Sciences Department, J. E. Funderburk and \\ J. Stavisky, Entomology and Nematology Department, and J. J. Marois, Plant Pathology Department, North Florida \\ Research and Education Center, University of Florida, IFAS, 155 Research Road, Quincy 32351
}

\begin{abstract}
Momol, M. T., Olson, S. M., Funderburk, J. E., Stavisky, J., and Marois, J. J. 2004. Integrated management of tomato spotted wilt on field-grown tomatoes. Plant Dis. 88:882-890.

Epidemics of spotted wilt caused by Tomato spotted wilt virus (TSWV) vectored by Frankliniella occidentalis and possibly other thrips species occur regularly in tomato in the southeastern United States. Field experiments were conducted to determine the effects of UV-reflective mulch, acibenzolar- $S$-methyl (plant activator), and insecticides on progress of tomato spotted wilt incidence and population dynamics of flower thrips (including F. occidentalis, F. tritici, and F. bispinosa). Whole plots of tomatoes grown on UV-reflective and black polyethylene mulch were divided into subplots of acibenzolar- $S$-methyl and no acibenzolar- $S$-methyl, and subsubplots of insecticide and no insecticide for thrips control. The UV-reflective mulch was more effective than black polyethylene mulch each year in reducing colonization of thrips in May and the consequent primary infections of tomato spotted wilt. Application of acibenzolar- $S$-methyl further reduced tomato spotted wilt incidence in 2000 and 2002, when disease pressure was great. Reproduction of thrips on tomato was poor in these experiments, but their control in the insecticide-treated sub-subplots prevented secondary spread in both years. The combination of UV-reflective mulch, acibenzolar- $S$-methyl, and insecticides was very effective in reducing tomato spotted wilt incidence in tomato.
\end{abstract}

Additional keywords: metalized mulch, methamidophos, spinosad

Over the past two decades, increased outbreaks of tomato spotted wilt (TSW) have occurred in a vast number of crops. TSW, caused by Tomato spotted wilt virus (TSWV), is a serious disease of many economically important crops, such as tomato, peanut, tobacco, pepper, and several ornamentals in the southeastern United States and elsewhere (17). TSWV is the type species of the genus Tospovirus in the family Bunyaviridae (25), and it is known to infect more than 1,000 plant species (5). The disease was originally described in Australia (3), with its etiology recognized later (36).

Eight species of thrips in two genera, Frankliniella and Thrips, are reported to transmit TSWV (17,24,51). Several Frankliniella species of thrips commonly infest tomatoes and other crops $(30,35)$. Some species, such as $F$. occidentalis and $F$. fusca, are known vectors of TSWV (24). F. bispinosa is a potential vector of TSWV (51), and another common species, $F$. tritici, is not a vector. In addition to differences in the capacity for virus transmission, these species differ in their phenol-

Corresponding author: M. T. Momol

E-mail: tmomol@ufl.edu

Accepted for publication 21 April 2004.

Publication no. D-2004-0608-01R

(C) 2004 The American Phytopathological Society ogy, population dynamics, host plant use, and behavior $(6,29,30,35)$.

TSWV replicates in F. occidentalis; thus the insect not only spreads the virus, but serves as a virus host (39). The virus is acquired only by the larvae (48), and the second instars and adults can transmit the virus to host plants (52). Usually primary spread of TSW is due to infections caused by incoming viruliferous adult thrips to a crop (i.e., tomato) from outside sources (i.e., host weed species outside of tomato fields [14]). Secondary spread caused by viruliferous thrips originates from primary infections within the field. For secondary spread, thrips need to colonize and reproduce on that season's crop and associated weeds. Adults persistently transmit TSWV, and their control with insecticides does not prevent transmission due to the short time of feeding necessary for infection to occur (26). Based on aggregation analyses, limited secondary spread of TSWV occurs within tomato and pepper fields, and primary spread is the most significant $(10,28)$.

Thrips and TSWV are still considered emerging problems on agricultural crops in the southern United States, although growers in Georgia and north Florida identified TSW and thrips as their most serious disease and insect problems (2). The conventional insecticide program for thrips consists of broad-spectrum insecticides (namely methamidophos) $(2,41)$. To date, no single control measure has been re- ported to be effective in reducing TSW incidence (39).

Individual growers in the southern United States typically responded to the threat of TSWV by applying broadspectrum insecticides on a calendar basis (2). The growers applied insecticides an average of 12.3 to 16.4 times per season in Georgia and north Florida, respectively. Yet extensive research has revealed that losses to solanaceous crops from TSWV in the southern United States typically are the result of primary infections, which are not prevented by such intensive insecticide use $(21,22,28)$. Furthermore, few insecticides are efficacious against $F$. occidentalis, and carbamate and organophosphate insecticides that have efficacy will not be available in the near future, or their use will be restricted as a result of cancellation during the re-registration process.

F. occidentalis may have multiple resistance mechanisms, and populations can develop cross-resistance to insecticides within the same chemical group and to those in other classes $(16,53)$. Spinosad (Spintor, Dow Agro Sciences, Indianapolis, IN) is a natural macrocyclic lactone insect control product with a unique mode of action. Laboratory bioassays have shown that spinosad is equally toxic to $F$. occidentalis, F. tritici, and F. bispinosa (9). However, F. bispinosa and $F$. tritici are rapid re-colonizers, and sometimes there is an apparent lack of control by spinosad for these species under field conditions $(29,32)$. Spinosad is a reduced-risk product due to its low mammalian toxicity and low environmental risks.

We have been investigating the benefits of other management tactics, including UV-reflective mulch. The importance of color (which affects reflected UV light) in host selection behavior by thrips has been reviewed (44). UV-reflective silvery mulches have been shown to reduce thrips colonization onto tomato $(4,12,18,37,40)$ and other crops $(32,50)$. Mulch painted silver $(12,33)$ and UV-reflective silver mulch (40) have been shown to reduce TSW incidence in tomato. The relative reflectance of UV wavelengths is important in determining whether $F$. occidentalis alights on a host (49).

Plants can activate protective mechanisms upon detection of invading pathogens. Protection expressed locally at the site of primary inoculation and systemically in tissues remote from the initial treatment is known as systemic acquired 
resistance (43). Acibenzolar- $S$-methyl (Actigard, Syngenta Inc., Greensboro, NC) is an inducer of systemic acquired resistance, and it is effective against a broad range of pathogens $(11,19)$. Acibenzolar- $S$ methyl in combination with imidacloprid was effective in reducing incidence of TSW on tobacco (27).

The objectives of this study were to determine the separate and combined effects of UV-reflective mulch, a systemic acquired resistance inducer, and reduced-risk insecticides, on incidence of tomato spotted wilt, vector thrips populations, and yield in field-grown tomatoes.

\section{MATERIALS AND METHODS}

Field preparation and planting. Field experiments were conducted in spring 2000, 2001, and 2002 at the North Florida Research and Education Center, Quincy (Gadsden County). The soil was an Orangeburg loamy fine sand. The plots were moldboard-plowed and doubledisked in early March. Fertilizer was diskincorporated in the $91-\mathrm{cm}$-wide bed area at the broadcast equivalent rate of 218-67$218 \mathrm{~kg} / \mathrm{ha}$ of N-P-K. Prior to experiment initiation, a combination of methyl bromide $(67 \%)$ and chloropicrin (33\%) was applied at a broadcast equivalent rate of $392 \mathrm{~kg}$ a.i./ha to the bed. Black polyethylene mulch $(1.25 \mathrm{mil})$ or reflective UV mulch (1.25 mil) (RepelGro Full Reflective Mulch, Reflectek Foils, Lake Zurich, IL) and drip tubing were laid concurrently with fumigant application. Beds were 8.67 $\mathrm{m}$ long, $0.91 \mathrm{~m}$ wide, and $1.8 \mathrm{~m}$ apart on centers. Each split-split plot consisted of four rows and a total of 68 plants. Plants were spaced $0.51 \mathrm{~m}$ apart within the row. Plots were separated from each other by $5.5 \mathrm{~m}$. Tomato plants (cultivar FL-47) were transplanted into each plot. Irrigation and foliar disease fungicides were applied as needed to promote good plant growth. Plants were staked and tied.

Integration of tactics against TSW and thrips. Experimental design was a randomized complete block with four and six replications in 2000 and 2001, respectively. Treatment arrangement was a splitsplit plot with black or UV-reflective mulch as the whole plot treatments, acibenzolar- $S$-methyl or no acibenzolar- $S$ methyl as the split plot treatments, and insecticide treatments as the split-split plot. Mulch type was selected as the whole plot because the mulch type can affect thrips on adjacent rows, and the whole plots were separated by a $5.5-\mathrm{m}$ buffer zone. The acibenzolar- $S$-methyl treatment was a regimen of applications: one spray at $1 \mathrm{~g}$ a.i. per 4,000 plants that was applied 1 week prior to transplanting and six sprays at 25.9 $\mathrm{g}$ a.i./ha that were begun immediately after transplanting and then every 2 weeks. Insecticide treatments for thrips were untreated, spinosad (0.07 kg a.i./ha), methamidophos $(0.4 \mathrm{~kg}$ a.i./ha), and spinosad $(0.07 \mathrm{~kg}$ a.i./ha) alternated with methamidophos (0.4 $\mathrm{kg}$ a.i./ha). The insecticides were applied on 27 April; 3, 10, 17, and 24 May; and 1 June in 2000. Dates of application in 2001 were 3, 9, 16, 23, and 30 May.

Percent disease incidence was determined by visual inspection of each plant in the two middle rows of each plot. On each disease assessment date, TSW visual symptoms were verified from 5 to 10 symptomatic plants using Immunochromatic device (TSWV ImmunoStrip, Agdia, Elkhart, IN). Symptomatic leaf tissue from the top of the plant was extracted at a ratio of 1:10 (wt/vol) and was chromatographed onto ImmunoStrip. One or two nonsymptomatic plants were tested as negative controls on each sample date. The presence of two bands indicated a positive TSWV. Disease incidence was assessed approximately every 2 weeks, and the area under the disease progress curve (AUDPC) was calculated (38).

Population densities of thrips were estimated twice weekly by random samples of 10 flowers per plot. Samples in 2000 were taken on 28 April and 2, 5, 9, 12, 16, 19, 23, 29, and 31 May. Samples in 2001 were taken on $4,8,11,15,18,22,25$, and 29 May and 2 and 6 June. Flowers were placed in vials containing $70 \%$ alcohol and returned to the laboratory for processing. Thrips adults were extracted and identified to species under a stereo-dissecting microscope at $\times 40$. For this extraction, the contents of the vial were placed in a petri dish, the flowers were torn apart using forceps, and each adult was examined for the diagnostic morphological characteristics for each species. The total numbers of thrips larvae were estimated, but individuals could not be identified to species.
Mature green and mature tomatoes were harvested twice each season from 12 healthy plants per plot and graded into marketable and unmarketable categories according to U.S. Department of Agriculture standards (47).

An analysis of variance (ANOVA) for a split-split plot randomized complete block design was used to determine the effects of treatments on thrips populations and disease incidence on individual sample dates and on seasonal totals of each thrips species. Efficacy of the insecticide treatments against each thrips species was evaluated using orthogonal comparisons to compare the seasonal totals. A square root transformation was used to normalize the percent disease incidence data (42). Differences in tomato yield were analyzed using ANOVA. Statistical analysis was performed with the SAS version 8.1 (SAS Institute, Cary, NC).

Effect of acibenzolar- $S$-methyl on TSWV. A randomized complete block experiment on black mulch without insecticides with four replications was conducted in the spring of 2002. Plot size was a single row by $10.5 \mathrm{~m}$ (20 plants per plot). The specific purpose of this experiment was to quantify the effect of acibenzolar- $S$ methyl on the incidence of TSW.

There were two treatments: a control and the same regimen of acibenzolar- $S$ methyl treatments used in the previous experiments. TSW incidence was recorded every 10 days from 30 April to 11 June, and symptoms were verified using ImmunoStrip test as previously described. On 21 May 2002, all nonsymptomatic plants in treated and untreated plots were tested for TSWV with ImmunoStrip. Disease incidence data were analyzed for a randomized complete block design using ANOVA.
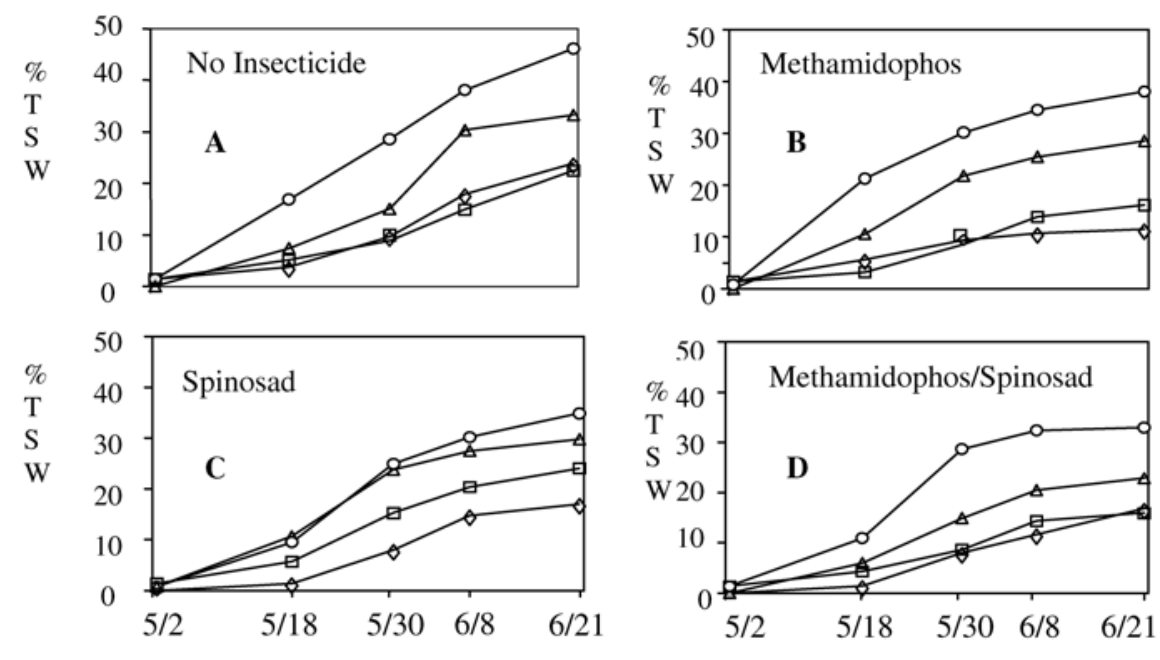

$$
\begin{aligned}
& \diamond \mathrm{UV} \text { - reflective mulch, } \\
& \text { acibenzolar- } S \text {-methyl }
\end{aligned}
$$

$\Delta$ Black mulch, acibenzolar- $S$-methyl

$\square$ UV-reflective mulch

- Black mulch

Fig. 1. Disease progress curves of tomato spotted wilt (TSW) as affected by mulch type, acibenzolar$S$-methyl, and insecticides in the experiment conducted in 2000. 


\section{RESULTS}

Effect of treatments on TSW incidence. Each of the plants tested showing visual TSW symptoms in 2000, 2001, and 2002 was positive by the ImmunoStrip test. Each of the symptomless plants tested was negative by the ImmunoStrip test.

An epidemic of TSW occurred in 2000, and the incidence of disease in the tomatoes started to increase in mid-May. In the plots not treated with insecticides, in- creases in disease incidence continued to progress in a linear fashion until harvest (Fig. 1A). In the insecticide-treated plots, the shape of the disease progress curves increased in a similar way until early June, when disease progress reached a plateau (Fig. 1B to D). The effect of the insecticide treatments on disease incidence was not significant until the last sampling date of 21 June 2000 (Table 1). The treatment effect of acibenzolar- $S$-methyl on disease

Table 1. $F$ and $P$ values from a split-split plot one way ANOVA of the effects of mulch, acibenzolar- $S$ methyl, and insecticide treatments on percent incidence of tomato spotted wilt (TSW) on disease assessment dates and the area under the disease progress curve (AUDPC) for TSW in experiments conducted in 2000 and 2001

\begin{tabular}{|c|c|c|c|c|c|c|}
\hline \multirow{2}{*}{$\begin{array}{l}\text { ANOVA } \\
\text { source }\end{array}$} & \multicolumn{2}{|c|}{ Mulch } & \multicolumn{2}{|c|}{ Acibenzolar-S-methyl } & \multicolumn{2}{|c|}{ Insecticide } \\
\hline & $\boldsymbol{F}$ & $P$ & $F$ & $P$ & $\boldsymbol{F}$ & $P$ \\
\hline 2000 & \multicolumn{2}{|c|}{$\mathrm{df}=1,3$} & \multicolumn{2}{|c|}{$\mathrm{df}=1,6$} & \multicolumn{2}{|c|}{$\mathrm{df}=3,36$} \\
\hline 02 May & 0.68 & 0.47 & 4.05 & 0.09 & 0.04 & 0.99 \\
\hline 18 May & 9.37 & 0.05 & 5.98 & 0.05 & 0.79 & 0.50 \\
\hline 30 May & 8.78 & 0.05 & 1.92 & 0.21 & 0.72 & 0.54 \\
\hline 08 June & 5.65 & 0.09 & 2.69 & 0.15 & 1.05 & 0.38 \\
\hline 21 June & 4.88 & 0.11 & 3.58 & 0.10 & 2.78 & 0.05 \\
\hline AUDPC & 5.70 & 0.09 & 8.27 & 0.02 & 0.94 & 0.43 \\
\hline 2001 & \multicolumn{2}{|c|}{$\mathrm{df}=1,5$} & \multicolumn{2}{|c|}{$\mathrm{df}=1,10$} & \multicolumn{2}{|c|}{$\mathrm{df}=3,60$} \\
\hline 11 May & 0.29 & 0.61 & 3.74 & 0.08 & 1.76 & 0.16 \\
\hline 21 May & 0.67 & 0.44 & 2.44 & 0.14 & 0.81 & 0.49 \\
\hline 05 June & 7.54 & 0.04 & 0.01 & 0.93 & 0.39 & 0.76 \\
\hline 22 June & 12.87 & 0.01 & 4.63 & 0.05 & 3.45 & 0.02 \\
\hline AUDPC & 5.39 & 0.06 & 0.08 & 0.78 & 1.12 & 0.34 \\
\hline
\end{tabular}

Table 2. Effect of mulch type, acibenzolar- $S$-methyl, and insecticides on final incidence of tomato spotted wilt in an experiment conducted in 2000

\begin{tabular}{lccc}
\hline & \multicolumn{3}{c}{ Final percent incidence of tomato spotted wilt $[ \pm \text { SEM }]^{\mathbf{a}}$} \\
\cline { 2 - 4 } Treatments & Acibenzolar-S-methyl & No acibenzolar-S-methyl & Mean \\
\hline Black mulch & & & \\
$\quad$ No insecticide & $33.3[7.8]$ & $46.3[7.1]$ & $39.8[5.5]$ \\
Methamidophos & $28.6[4.0]$ & $38.2[6.7]$ & $33.4[4.0]$ \\
Spinosad & $29.8[4.9]$ & $34.9[9.7]$ & $32.3[5.1]$ \\
Methamidophos/spinosad & $23.0[4.0]$ & $33.0[6.4]$ & $28.0[4.0]$ \\
Mean & $28.7[2.6]$ & $38.1[3.6]$ & $33.4[2.4]$ \\
UV-reflective mulch & & & \\
No insecticide & $23.8[7.3]$ & $22.5[6.2]$ & $23.1[4.4]$ \\
Methamidophos & $11.4[0.9]$ & $16.2[4.4]$ & $13.8[2.3]$ \\
Spinosad & $17.1[2.0]$ & $24.1[6.6]$ & $20.6[3.5]$ \\
Methamidophos/spinosad & $16.9[4.4]$ & $16.0[2.9]$ & $16.4[2.4]$ \\
Mean & $17.3[2.3]$ & $19.7[2.5]$ & $18.5[1.7]$ \\
\hline
\end{tabular}

${ }^{a}$ Figures in brackets indicate standard error of means [SEM].

Table 3. Effect of mulch, acibenzolar- $S$-methyl, and insecticides on final incidence of tomato spotted wilt in an experiment conducted in 2001

\begin{tabular}{lccc}
\hline & \multicolumn{3}{c}{ Final percent tomato spotted wilt incidence $[ \pm \text { SEM }]^{\mathbf{a}}$} \\
\cline { 2 - 4 } Treatments & Acibenzolar-S-methyl & No acibenzolar-S -methyl & Mean \\
\hline Black mulch & & & \\
No insecticide & $8.5[2.4]$ & $9.8[1.0]$ & $9.1[1.6]$ \\
Methamidophos & $6.1[1.0]$ & $8.7[3.1]$ & $7.4[1.6]$ \\
Spinosad & $6.4[2.1]$ & $7.4[1.1]$ & $6.9[1.1]$ \\
Methamidophos/spinosad & $7.0[1.6]$ & $6.9[1.4]$ & $7.0[1.0]$ \\
Mean & $7.0[0.9]$ & $8.2[1.0]$ & $7.6[0.7]$ \\
UV-reflective mulch & & & \\
No insecticide & $3.9[1.6]$ & $6.5[2.3]$ & $5.2[1.4]$ \\
Methamidophos & $1.4[0.8]$ & $1.4[0.3]$ & $1.4[0.4]$ \\
Spinosad & $2.8[0.5]$ & $2.8[0.7]$ & $2.8[0.4]$ \\
Methamidophos/spinosad & $1.1[0.8]$ & $3.7[1.5]$ & $2.4[0.9]$ \\
Mean & $2.3[0.5]$ & $3.6[0.8]$ & $2.9[0.5]$ \\
\hline
\end{tabular}

${ }^{a}$ Figures in brackets indicate standard error of means [SEM].

incidence approached significance on 2 May and 21 June 2000, and it was significant on 18 May 2000. The overall season effect of acibenzolar- $S$-methyl, as determined by the AUDPC, was significant in 2000. The incidence of TSW was significantly less in tomatoes grown on UVreflective than on black mulch on 18 and 30 May 2000, and it approached significance on 8 and 21 June 2000. The effect of mulch for the AUDPC approached significance (Table 1).

The effects of mulch, acibenzolar- $S$ methyl, and insecticides on the final incidence of disease in 2000 are shown in Table 2. Both acibenzolar-S-methyl and the insecticide treatments reduced the incidences of disease in the plots of black mulch. The whole plot treatment, UVreflective mulch, significantly reduced the final incidences of disease with or without acibenzolar-S-methyl and insecticides. Disease incidence was reduced from 46.3 to $11.4 \%$ in tomatoes grown on UVreflective mulch treated with acibenzolar$S$-methyl and methamidophos compared with untreated tomatoes grown on black mulch.

In 2001, the effect of acibenzolar- $S$ methyl on disease incidence approached significance on 11 May, and it was significant on 22 June (Table 1). The overall effect of acibenzolar- $S$-methyl, based on the AUDPC, was not significant. The effect of mulch on TSW incidence was significant on 5 and 22 June. The AUDPC was not significant for mulch in 2001. Insecticides significantly reduced incidence of disease only on the last sample date in 2001. On 22 June 2001, the final incidences of TSW were $<10 \%$ in all treatments (Table 3).

Effect of acibenzolar- $S$-methyl on TSW incidence in 2002. Disease progress in 2002 is shown in Figure 2. The regimen of acibenzolar- $S$-methyl applications resulted in a significantly reduced incidence of disease on 21 May. Differences in disease incidence between treatments were not significant on later sample dates.

Effects of treatments on populations of thrips. Populations of $F$. occidentalis, $F$. bispinosa, and F. tritici peaked in midMay each season (Figs. 3 and 4). The percentages of $F$. occidentalis, $F$. tritici, and $F$. bispinosa in 2000 in the untreated plots were 30,57 , and $12 \%$, respectively. The percentages of $F$. occidentalis, $F$. tritici, and $F$. bispinosa in 2001 were 9, 87, and $3 \%$, respectively. The numbers of larvae were much lower on all sample dates than the numbers of adults. The percentages of larval thrips in the untreated plots were 5 and 6\% in 2000 and 2001, respectively.

Populations of adult thrips were lower in tomatoes grown on the highly UVreflective compared with the black mulch on sample dates from early flowering to late May (Figs. 3 and 4). Differences were significant for $F$. occidentalis on 4 April 


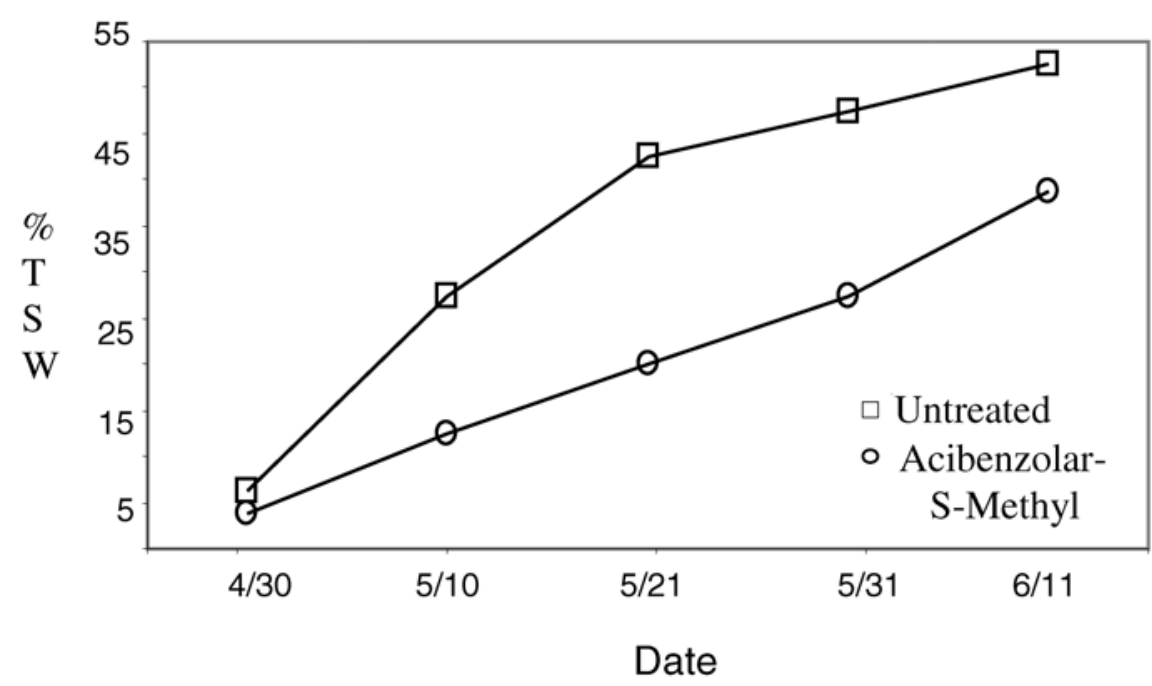

Fig. 2. Disease progress curves of tomato spotted wilt (TSW) as affected by acibenzolar- $S$-methyl in the experiment conducted in 2002. and 2 and 5 May in 2000 and on 4 and 8 May in 2001 (Table 4). Differences were significant for $F$. tritici on 28 April and 2 and 5 May in 2000 and on 4, 8, 11, 18, 22, and 25 May in 2001. Differences were significant for $F$. bispinosa on 2, 12, 19, and 31 May in 2000 and on 4, 11, and 18 May in 2001.

The numbers of larvae in all treatments were much smaller than those of adults, indicating that the thrips reproduced poorly (Figs. 3 and 4). Numbers of larvae were significantly lower in tomatoes grown on the highly UV-reflective versus the black mulch on 28 April in 2000 and on 28 April and 2, 9, and 12 May in 2001 (Table 4). Conversely, the numbers of larvae were significantly greater in tomatoes grown on the UV-reflective versus black mulch on 29 May 2000.

All insecticide treatments were very effective in reducing populations of thrips

\section{UV-reflective mulch}

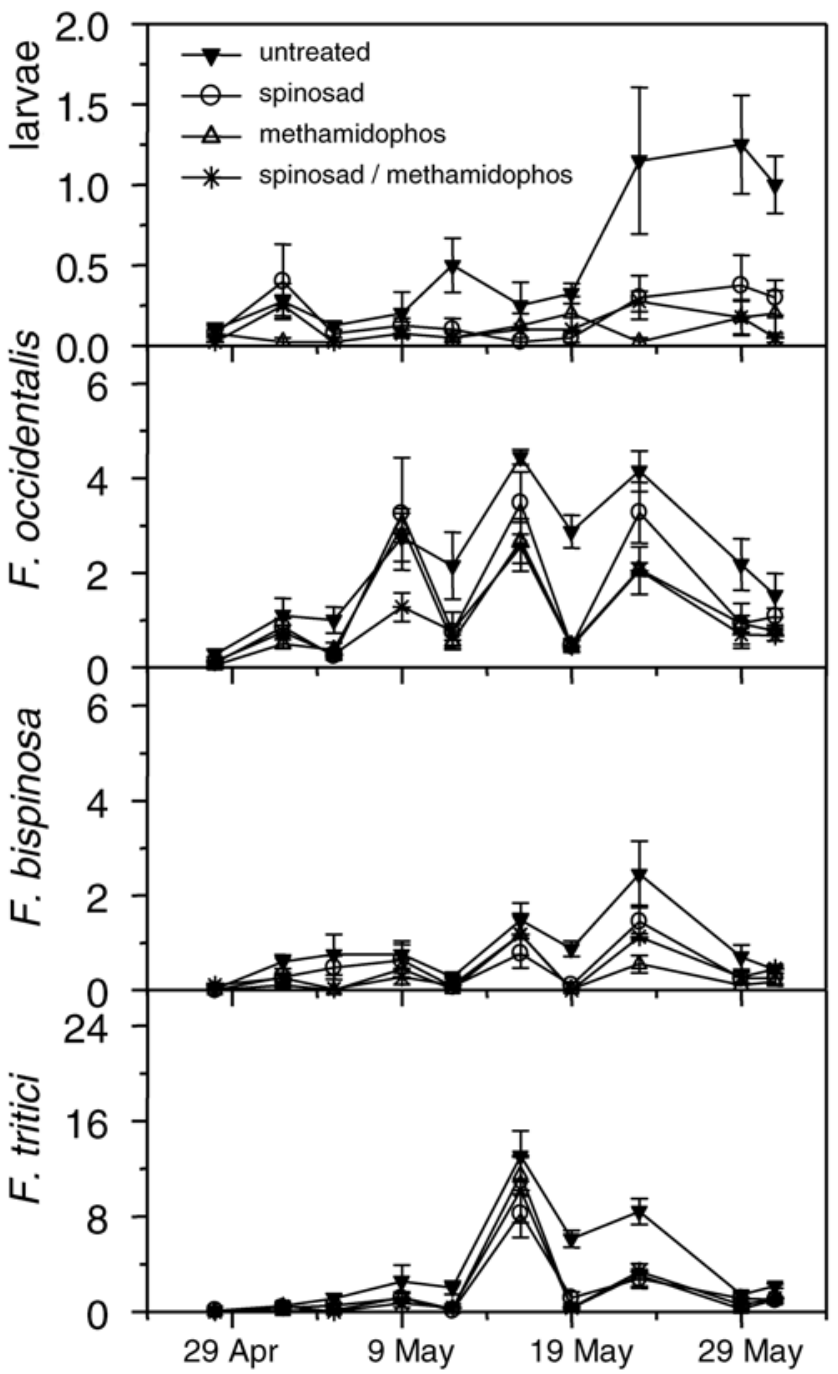

Black mulch

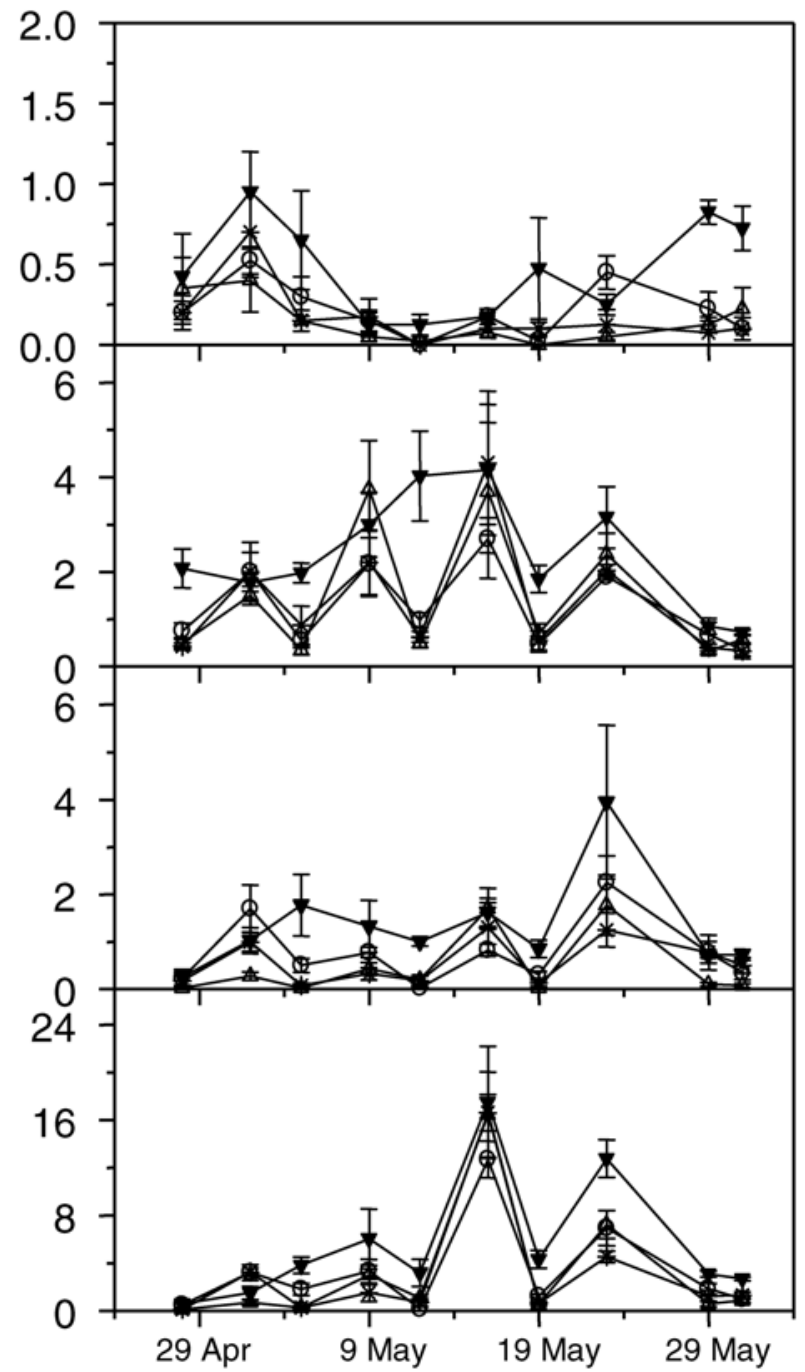

\section{Spring 2000}

Fig. 3. Mean numbers of Frankliniella tritici, F. bispinosa, F. occidentalis, and larval thrips per flower ( \pm SEM) from 28 April through 31 May 2000 on tomatoes grown on UV-reflective and black mulch in untreated and insecticide-treated plots. 
(Figs. 3 and 4). The effect of insecticide treatment was significant for the adults of F. occidentalis on seven dates in 2000 and on 10 dates in 2001 (Table 4). The insecticides significantly reduced the adults of $F$. tritici on nine dates in 2000 and on 10 dates in 2001. The insecticides significantly reduced populations of $F$. bispinosa on 10 dates in 2000 and on eight dates in 2001. The insecticides significantly reduced the larvae on nine dates in 2000 and on eight dates in 2001. When orthogonal comparisons were used to compare the seasonal totals of thrips in each insecticide treatment, spinosad was significantly more effective than the other insecticide treatments in 2000 against the adults of $\mathrm{F}$. occidentalis and $F$. bispinosa, and the thrips larvae $(F=6.2,4.9$, and 31.8 , respectively; $\mathrm{df}=1,36 ; P<0.05,0.05$, and 0.001 , respectively). Spinosad was significantly more effective than the other insecticide treatments in 2001 against the adults of $F$. occidentalis and thrips larvae $(F=30.0$ and 9.8 , respectively; $\mathrm{df}=1,60 ; P<0.001$ and 0.005 , respectively). The treatment of spinosad/methamidophos in alternate weeks was significantly more effective than the treatment of methamidophos alone in 2000 against the adults of $F$. occidentalis, the adults of $F$. bispinosa, and the thrips larvae $(F=4.9,6.0$, and 24.2 , respectively; df $=1,36 ; P<0.05$, 0.05 , and 0.001 , respectively) and in 2001 against the adults of $F$. occidentalis and the thrips larvae $(F=18.3$ and 7.6 , respectively; $\mathrm{df}=1,60 ; P<0.001$ and 0.01 , respectively).

The effect of acibenzolar-S-methyl on the number of thrips was significant on some dates for the adults of each species (Table 4). The mean numbers of $F$. occidentalis per flower $( \pm$ SEM $)$ in untreated and treated tomato were significantly different on 5 May $(0.71 \pm 0.06$ versus $0.38 \pm$ 0.12 , respectively) and 9 May $(2.68 \pm 0.26$ versus $1.91 \pm 0.21$, respectively) in 2000 and on 4 May $(0.26 \pm 0.05$ versus $0.18 \pm$ 0.04 , respectively), 8 May $(0.61 \pm 0.06$ versus $0.41 \pm 0.05$, respectively), 15 May $(1.10 \pm 0.10$ versus $0.74 \pm 0.07$, respectively), 18 May $(0.89 \pm 0.09$ versus $0.65 \pm$ 0.06 , respectively), and 25 May $(0.58 \pm$ 0.08 versus $0.42 \pm 0.06$, respectively) in 2001. Numbers of $F$. tritici were significantly greater in untreated versus tomatoes treated with acibenzolar- $S$-methyl on 2 May $(1.26 \pm 0.24$ versus $0.71 \pm 0.14$, respectively) and 5 May (1.00 \pm 0.24 versus $0.36 \pm 0.08$, respectively) in 2000 , and conversely, numbers were greater in treated versus untreated tomatoes on 29 May $(2.22 \pm 0.23$ versus $2.79 \pm 0.23$, respectively) in 2001. Numbers of $F$. bispinosa were significantly greater in untreated versus tomatoes treated with acibenzolar- $S$-methyl on 2 May $(0.65 \pm$ 0.12 versus $0.25 \pm 0.05$, respectively), 5 May $(0.45 \pm 0.14$ versus $0.23 \pm 0.06$, re-
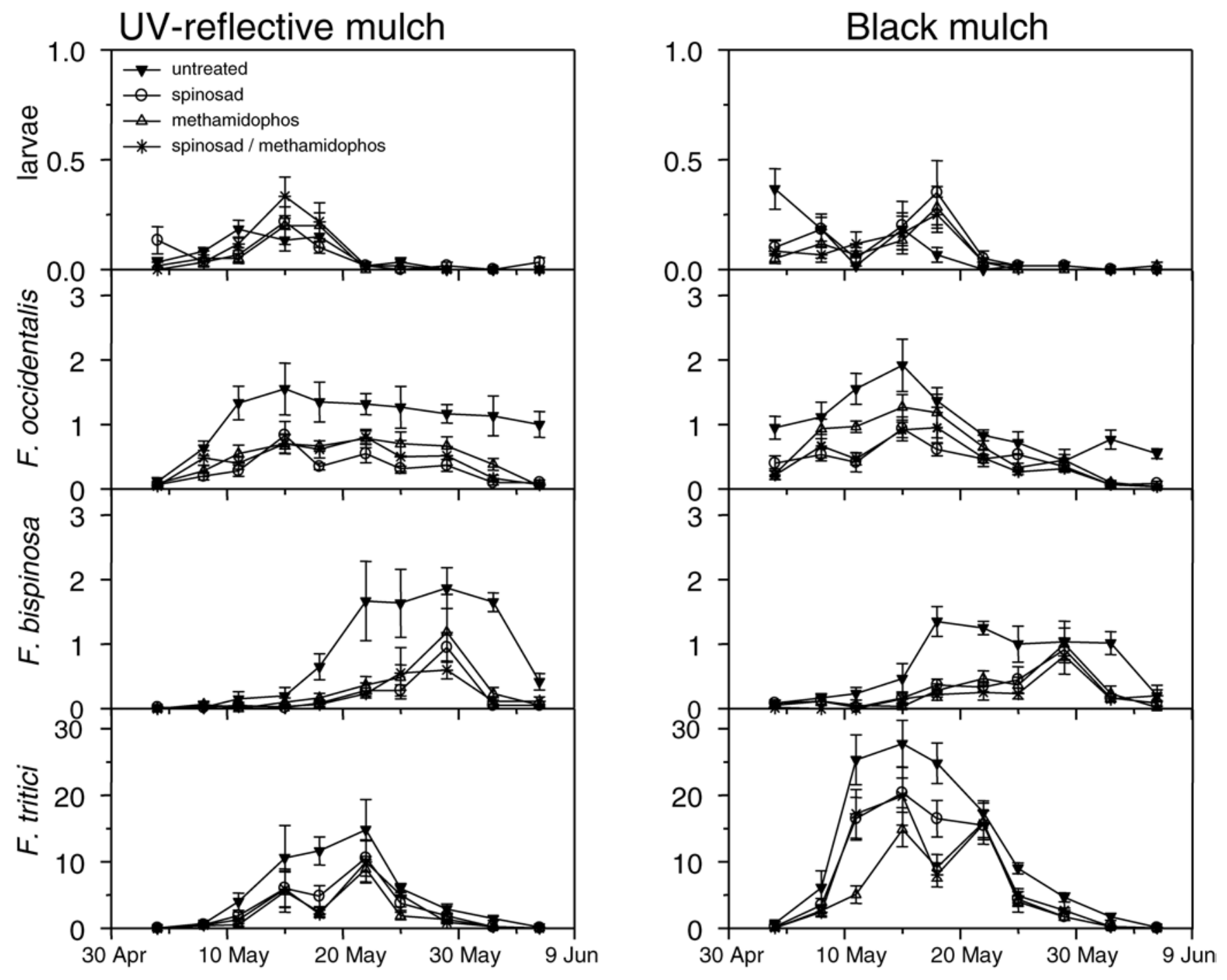

Spring 2001

Fig. 4. Mean numbers of Frankliniella tritici, F. bispinosa, F. occidentalis, and larval thrips per flower ( \pm SEM) from 4 May through 6 June 2001 on tomatoes grown on UV-reflective and black mulch in untreated and insecticide-treated plots. 
spectively), and 12 May (0.23 \pm 0.06 versus $0.13 \pm 0.03$, respectively) in 2000 .

Effect of treatments on yield. Acibenzolar- $S$-methyl and insecticide treatment increased tomato yield significantly, and the effect of mulch on yield was not significant in 2000 (Table 5). Marketable yields were increased by the UV-reflective versus the black mulch in 2001 (Table 6). Yield was significantly increased by the applications of the insecticides in 2001. Yields of tomato grown in acibenzolar- $S$ methyl plots were not significantly greater than in the control plots in 2001 (Table 6).

\section{DISCUSSION}

The UV-reflective mulch was effective in reducing colonization of the adults of $F$. occidentalis in late April and early May (Figs. 3 and 4). During the TSW epidemic in 2000, the primary spread of TSW was reduced early in the season in tomatoes grown on UV-reflective mulch versus black mulch (Fig. 1). The benefits of UVreflective mulch in reducing the numbers of thrips declined by mid-May as the plants grew and covered the mulch. The spread of TSW increased similarly on both mulches later in the 2000 growing season. Greer and Dole (13) reviewed 28 studies in which the effects of either aluminum or aluminum-painted mulch on insect, insectvectored viruses, and crop yield were evaluated. In most studies, aphids and thrips were significantly repelled, while the effects on whitefly numbers in different studies were variable. Insect-vectored viruses were reduced and yield increased in most studies. They speculated that the brightness of the mulch and the variability in the reflected spectra between mulches affected the results in individual studies. Aluminum-painted mulch reflects light in the B (400 to $500 \mathrm{~nm}$ ) and near-UV (395 $\mathrm{nm})$ regions of the spectrum (8). Reflectance in these wavelengths of the aluminum mulch used in the present study is $>80 \%$ (Reflectek Foils, Lake Zurich, IL).

The applications of acibenzolar-Smethyl were effective in reducing the incidence of TSW in tomatoes grown on black mulch early in the growing season in 2000 and 2002 (Figs. 1 and 2, Table 1). The effectiveness of acibenzolar-S-methyl, in combination with insecticides, against TSWV was previously demonstrated on tobacco $(7,27)$. Disease incidence was not significantly reduced in acibenzolar- $S$ methyl-treated tomatoes grown on the UVreflective mulch, undoubtedly because the UV-reflective mulch was very effective in reducing the primary spread of TSWV early in the growing season. The regimen of acibenzolar- $S$-methyl applications applied to tomatoes on black mulch without insecticides for thrips control reduced the incidence of TSW by $28.0 \%$ in 2000 . A similar reduction of $28.0 \%$ was observed in the plots in the other epidemic year of 2002 (Fig. 2).

We conclude that acibenzolar-S-methyl is effective in reducing the incidence of TSW in tomato when natural infection pressure is high, as in the 2000 and 2002 experiments (Figs. 1 and 2, Table 1). More research is needed to further evaluate the benefits of varying the rates and timings of applications. The efficacy of acibenzolar$S$-methyl in combination with imidacloprid (a systemic insecticide) on TSWV was first discovered on tobacco $(7,27)$. Their results indicated that ELISA-positive samples were much higher than the observed number of symptomatic plants. In our experiment in 2002, symptomless plants were free of TSWV based on the ImmunoStrip test. This discrepancy might be due to the higher level of sensitivity of the regular ELISA used in the Csinos et al. (7) study and the less sensitive ImmunoStrip used in this study. It may also be due to a higher percentage of visual symptom expression in infected tomato versus infected tobacco.

The application of acibenzolar- $S$-methyl affected thrips numbers on some dates (Table 4). This is not unexpected in that acibenzolar- $S$-methyl substitutes for the natural systemic-acquired-resistance signal molecule salicylic acid that is essential for

Table 4. $F$ and $P$ values from ANOVA of treatment effects of mulch, acibenzolar-S-methyl, and insecticides on numbers of $F$ rankliniella occidentalis, $F$. tritici, $F$. bispinosa, and thrips larvae in tomato on 10 dates each year in experiments conducted in Quincy, FL, in 2000 and 2001

\begin{tabular}{|c|c|c|c|c|c|c|c|c|c|c|c|c|c|c|c|c|c|c|c|c|c|}
\hline $\begin{array}{l}\text { ANOVA } \\
\text { source }\end{array}$ & df & $\boldsymbol{F}$ & $P$ & $F$ & $\boldsymbol{P}$ & $\boldsymbol{F}$ & $P$ & $\boldsymbol{F}$ & $P$ & $F$ & $\boldsymbol{P}$ & $F$ & $\boldsymbol{P}$ & $F$ & $\boldsymbol{P}$ & $F$ & $\boldsymbol{P}$ & $F$ & $\boldsymbol{P}$ & $F$ & $P$ \\
\hline 2000 & & \multicolumn{2}{|c|}{$28 \mathrm{Apr}$} & \multicolumn{2}{|c|}{2 May } & \multicolumn{2}{|c|}{5 May } & \multicolumn{2}{|c|}{9 May } & \multicolumn{2}{|c|}{12 May } & \multicolumn{2}{|c|}{16 May } & \multicolumn{2}{|c|}{19 May } & \multicolumn{2}{|c|}{23 May } & \multicolumn{2}{|c|}{29 May } & \multicolumn{2}{|c|}{31 May } \\
\hline \multicolumn{22}{|l|}{ F. occidentalis } \\
\hline Mulch & 1,3 & 34.1 & 0.01 & 77.5 & 0.003 & 11.3 & 0.04 & 0.0 & 0.91 & 0.5 & 0.52 & 0.7 & 0.46 & 4.5 & 0.13 & 4.6 & 0.12 & 21.9 & 0.02 & 16.2 & 0.03 \\
\hline Acibenzolar & 1,6 & 0.1 & 0.77 & 1.4 & 0.27 & 15.0 & 0.008 & 6.2 & 0.05 & 0.5 & 0.53 & 0.2 & 0.69 & 0.0 & 0.93 & 2.0 & 0.21 & 0.4 & 0.53 & 1.7 & 0.25 \\
\hline Insecticide & 3,36 & 31.0 & 0.001 & 1.1 & 0.37 & 20.9 & 0.001 & 0.8 & 0.51 & 24.6 & 0.001 & 2.2 & 0.11 & 26.7 & 0.001 & 9.5 & 0.001 & 7.9 & 0.001 & 9.9 & 0.001 \\
\hline \multicolumn{22}{|l|}{ F. tritici } \\
\hline Mulch & 1,3 & 12.7 & 0.04 & 62.3 & 0.004 & 23.5 & 0.02 & 3.1 & 0.18 & 6.0 & 0.09 & 7.4 & 0.07 & 0.0 & 0.86 & 85.8 & 0.003 & 14.5 & 0.03 & 3.2 & 0.17 \\
\hline Acibenzolar & 1,6 & 0.1 & 0.82 & 24.5 & 0.003 & 72.4 & 0.001 & 3.9 & 0.10 & 1.8 & 0.23 & 1.4 & 0.28 & 2.8 & 0.15 & 1.7 & 0.24 & 0.9 & 0.39 & 2.1 & 0.20 \\
\hline Insecticide & 3,36 & 10.4 & 0.001 & 7.1 & 0.001 & 25.1 & 0.001 & 5.0 & 0.006 & 20.1 & 0.001 & 2.3 & 0.10 & 68.3 & 0.001 & 21.9 & 0.001 & 15.2 & 0.001 & 16.8 & 0.001 \\
\hline \multicolumn{22}{|l|}{ F. bispinosa } \\
\hline Mulch & 1,3 & 5.6 & 0.10 & 49.1 & 0.006 & 7.6 & 0.07 & 0.2 & 0.72 & 25.0 & 0.01 & 1.8 & 0.27 & 15.3 & 0.03 & 5.1 & 0.11 & 3.9 & 0.14 & 112.4 & 0.002 \\
\hline Acibenzolar & 1,6 & 0.1 & 0.77 & 39.0 & 0.001 & 5.6 & 0.06 & 3.6 & 0.10 & 10.1 & 0.02 & 0.5 & 0.52 & 4.3 & 0.08 & 1.5 & 0.27 & 0.0 & 0.98 & 0.0 & 0.95 \\
\hline Insecticide & 3,36 & 5.3 & 0.004 & 5.4 & 0.02 & 12.4 & 0.001 & 3.7 & 0.02 & 33.3 & 0.001 & 3.0 & 0.04 & 32.0 & 0.001 & 12.6 & 0.001 & 9.0 & 0.001 & 4.4 & 0.01 \\
\hline \multicolumn{22}{|c|}{ Frankliniella spp. larvae } \\
\hline Mulch & 1,3 & 10.2 & 0.05 & 4.5 & 0.12 & 7.0 & 0.08 & 1.4 & 0.32 & 1.5 & 0.31 & 2.5 & 0.21 & 0.0 & 0.85 & 0.9 & 0.42 & 9.5 & 0.05 & 1.7 & 0.23 \\
\hline Acibenzolar & 1,6 & 1.5 & 0.27 & 0.15 & 0.71 & 0.2 & 0.67 & 0.5 & 0.52 & 0.5 & 0.52 & 0.7 & 0.44 & 0.2 & 0.71 & 4.3 & 0.08 & 0.7 & 0.44 & 0.4 & 0.30 \\
\hline Insecticide & 3,36 & 0.3 & 0.85 & 5.7 & 0.003 & 7.0 & 0.001 & 4.1 & 0.01 & 16.2 & 0.001 & 6.1 & 0.002 & 8.5 & 0.001 & 19.7 & 0.001 & 37.7 & 0.001 & 21.0 & 0.001 \\
\hline 2001 & & \multicolumn{2}{|c|}{4 May } & \multicolumn{2}{|c|}{8 May } & \multicolumn{2}{|c|}{11 May } & \multicolumn{2}{|c|}{15 May } & \multicolumn{2}{|c|}{18 May } & \multicolumn{2}{|c|}{22 May } & \multicolumn{2}{|c|}{25 May } & 29 & May & & Jun & & un \\
\hline F. occidentalis & & & & & & & & & & & & & & & & & & & & & \\
\hline Mulch & 1,5 & 19.3 & 0.007 & 34.8 & 0.002 & 2.1 & 0.20 & 5.6 & 0.06 & 3.8 & 0.11 & 2.6 & 0.18 & 3.8 & 0.11 & 3.3 & 0.13 & 4.1 & 0.10 & 5.6 & 0.06 \\
\hline Acibenzolar & 1,10 & 6.1 & 0.03 & 7.3 & 0.02 & 1.3 & 0.28 & 9.3 & 0.01 & 5.5 & 0.04 & 1.2 & 0.31 & 5.6 & 0.04 & 0.1 & 0.83 & 0.1 & 0.79 & 0.2 & 0.67 \\
\hline Insecticide & 3,60 & 16.7 & 0.001 & 7.3 & 0.001 & 36.3 & 0.001 & 18.1 & 0.001 & 18.4 & 0.001 & 6.3 & 0.001 & 8.8 & 0.001 & 21.6 & 0.001 & 42.1 & 0.001 & 59.9 & 0.001 \\
\hline F. tritici & & & & & & & & & & & & & & & & & & & & & \\
\hline Mulch & 1,5 & 33.3 & 0.002 & 13.1 & 0.02 & 72.3 & 0.001 & 5.1 & 0.07 & 44.7 & 0.001 & 13.4 & 0.01 & 18.9 & 0.007 & 5.0 & 0.08 & 0.6 & 0.47 & 0.8 & 0.42 \\
\hline Acibenzolar & 1,10 & 0.6 & 0.47 & 3.4 & 0.10 & 2.2 & 0.17 & 0.3 & 0.61 & 0.0 & 0.85 & 0.2 & 0.66 & 0.1 & 0.78 & 9.4 & 0.01 & 2.6 & 0.14 & 1.1 & 0.32 \\
\hline Insecticide & 3,60 & 15.8 & 0.001 & 4.7 & 0.005 & 77.9 & 0.001 & 9.4 & 0.001 & 71.2 & 0.001 & 3.8 & 0.01 & 24.5 & 0.001 & 22.3 & 0.001 & 40.9 & 0.001 & 5.0 & 0.004 \\
\hline F. bispinosa & & & & & & & & & & & & & & & & & & & & & \\
\hline Mulch & 1,5 & 7.5 & 0.04 & 5.6 & 0.06 & 33.4 & 0.002 & 5.1 & 0.07 & 12.2 & 0.02 & 0.3 & 0.59 & 0.7 & 0.43 & 0.5 & 0.53 & 0.9 & 0.38 & 2.1 & 0.20 \\
\hline Acibenzolar & 1,10 & 3.9 & 0.08 & 1.0 & 0.34 & 2.1 & 0.17 & 4.4 & 0.06 & 0.0 & 0.89 & 0.2 & 0.65 & 0.0 & 0.95 & 0.3 & 0.60 & 10.0 & 0.01 & 0.1 & 0.73 \\
\hline Insecticide & 3,60 & 5.8 & 0.002 & 1.0 & 0.40 & 7.1 & 0.001 & 5.7 & 0.002 & 24.4 & 0.001 & 5.5 & 0.002 & 7.4 & 0.001 & 4.0 & 0.01 & 15.6 & 0.001 & 0.5 & 0.67 \\
\hline Frankliniella $\mathrm{s}$ & spp. la & rvae & & & & & & & & & & & & & & & & & & & \\
\hline Mulch & 1,5 & 7.9 & 0.04 & 28.4 & 0.003 & 2.8 & 0.15 & 6.3 & 0.05 & 14.6 & 0.01 & 2.2 & 0.20 & 1.3 & 0.31 & 0.2 & 0.69 & 2.7 & 0.16 & 0.4 & 0.56 \\
\hline Acibenzolar & 1,10 & 0.1 & 0.80 & 0.1 & 0.72 & 0.6 & 0.46 & 0.5 & 0.50 & 2.7 & 0.13 & 0.0 & 1.0 & 0.6 & 0.46 & 5.1 & 0.05 & 3.6 & 0.09 & 3.1 & 0.11 \\
\hline Insecticide & 3,60 & 2.7 & 0.06 & 2.3 & 0.08 & 6.9 & 0.001 & 6.1 & 0.001 & 17.3 & 0.001 & 22.9 & 0.001 & 11.3 & 0.001 & 15.3 & 0.001 & 45.7 & 0.001 & 15.7 & 0.001 \\
\hline
\end{tabular}


activation of systemic acquired resistance (41). Thaler et al. $(45,46)$ showed that induction of defensive proteins in plants by application of salicylic acid provided resistance to certain insects, including thrips.

Periods of intense flight activity or "mass flights" of flower thrips occur in many geographical regions. Mass flights of $F$. occidentalis, F. tritici, and F. bispinosa are typical in north Florida during late April and early May when the adults disperse in large numbers from wild hosts and colonize crop fields $(35,40)$. In this study, each of the insecticide treatments was effective against the thrips adults and the larvae (Figs. 3 and 4). The residual efficacy of insecticide treatments was short, and the numbers of adults in the flowers usually rebounded between the weekly applications due to re-colonization. Attempts to control populations of $F$. occidentalis by regular applications of insecti- cides have led to the development of resistance to most classes of insecticides (16). Methamidophos and spinosad are insecticides in different chemical classes with different modes of action (9). Therefore, alternating applications of spinosad and methamidophos for thrips control during the season is recommended as an integrated resistance management strategy.

The most common vector of TSWV in this study was F. occidentalis (Figs. 3 and 4). F. occidentalis is considered the key vector in tomatoes in northern Florida $(31,40)$. The role of $F$. bispinosa in disease epidemiology remains unclear. In laboratory experiments this species successfully acquired and transmitted the TSWV in pepper (Y. Avila and J. Funderburk, unpublished data) and other plant hosts (51). The insecticides significantly suppressed populations of $F$. occidentalis and $F$. bispinosa in May when numbers in the tomato flow-

Table 5. Effect of mulch, acibenzolar- $S$-methyl, and insecticides on marketable yield of tomatoes in an experiment conducted in 2000

\begin{tabular}{lccc}
\hline & \multicolumn{3}{c}{ Marketable yield kg/ha [ \pm SEM $]^{\mathbf{a}}$} \\
\cline { 2 - 4 } Treatment & Acibenzolar-S-methyl & No acibenzolar-S-methyl & Mean \\
\hline Black mulch & & & \\
No insecticide & $10,867[3,269]$ & $4,589[2,077]$ & $7,729[2,149]$ \\
Methamidophos & $21,359[4,286]$ & $13,088[2,415]$ & $17,224[2,761]$ \\
Spinosad & $16,746[5,160]$ & $9,623[2,450]$ & $13,184[2,968]$ \\
Methamidophos/spinosad & $21,306[4,715]$ & $13,622[1,704]$ & $17,464[2,737]$ \\
Mean & $17,570[2,264]$ & $10,231[1,347]$ & $13,900[1,453]$ \\
UV-reflective mulch & & & \\
No insecticide & $5,461[1,005]$ & $3,763[589]$ & $4,612[627]$ \\
Methamidophos & $23,508[2,829]$ & $21,150[1,272]$ & $22,329[1,503]$ \\
Spinosad & $19,944[2,946]$ & $9,061[3,890]$ & $14,504[3,055]$ \\
Methamidophos/spinosad & $18,641[2,935]$ & $17,376[1,358]$ & $18,009[1,515]$ \\
Mean & $16,888[2,104]$ & $12,838[2,012]$ & $14,863[1,477]$ \\
ANOVA sources & $\mathrm{df}$ & $F$ & $P$ \\
Mulch & 1,3 & 0.25 & 0.65 \\
Acibenzolar- $S$-methyl & 1,6 & 7.35 & 0.03 \\
Insecticide & 3,36 & 23.06 & 0.0001 \\
Interactions are not significant & & & \\
\hline
\end{tabular}

${ }^{\text {a }}$ Figures in brackets indicate standard error of means [SEM].

Table 6. Effect of mulch, acibenzolar-S-methyl, and insecticides on marketable yield of tomatoes in an experiment conducted in 2001

\begin{tabular}{|c|c|c|c|}
\hline \multirow[b]{2}{*}{ Treatment } & \multicolumn{3}{|c|}{ Marketable yield kg/ha $[ \pm \mathrm{SEM}]^{\mathrm{a}}$} \\
\hline & Acibenzolar-S-methyl & No acibenzolar-S-methyl & Mean \\
\hline \multicolumn{4}{|l|}{ Black mulch } \\
\hline No insecticide & $32,480[4,244]$ & $27,046[2,016]$ & $29,762[2,385]$ \\
\hline Methamidophos & $41,016[3,969]$ & $38,316[4,114]$ & $39,665[2,755]$ \\
\hline Spinosad & $33,557[4,163]$ & $37,180[4,148]$ & $35,368[2,854]$ \\
\hline Methamidophos/spinosad & $40,009[3,846]$ & $39,233[3,147]$ & $39,622[2,372]$ \\
\hline Mean & $36,766[2,049]$ & $35,444[1,912]$ & $36,105[1,389]$ \\
\hline \multicolumn{4}{|l|}{ UV-reflective mulch } \\
\hline No insecticide & $31,356[3,642]$ & $29,463[4,002]$ & $30,410[2,596]$ \\
\hline Methamidophos & $53,418[3,828]$ & $43,382[4,400]$ & $48,399[3,165]$ \\
\hline Spinosad & $42,002[6,090]$ & $42,758[5,237]$ & $42,380[3,830]$ \\
\hline Methamidophos/spinosad & $52,876[5,361]$ & $45,604[4,674]$ & $49,240[3,563]$ \\
\hline Mean & $44,913[2,627]$ & $40,302[2,520]$ & $42,607[1,945]$ \\
\hline ANOVA sources & df & $F$ & $P$ \\
\hline Mulch & 1,5 & 7.95 & 0.03 \\
\hline Acibenzolar-S-methyl & 1,10 & 1.95 & 0.19 \\
\hline Insecticide & 3,60 & 18.93 & 0.0001 \\
\hline Interactions are not signifi & & & \\
\hline
\end{tabular}

${ }^{a}$ Figures in brackets indicate standard error of means [SEM]. ers peaked, but there was no effect on the incidence of TSW, which increased most from middle to late May (Fig. 1, Table 1). Our results support other conclusions (28) that progress of TSW in tomatoes in northern Florida is more the result of primary spread rather than secondary spread and that control of the adults with insecticides is ineffective in preventing primary infections. McPherson et al. $(21,22)$ reported that insecticides were ineffective in preventing primary disease spread in tobacco.

Tomato is not a reproductive host for $F$. tritici and F. bispinosa, and it is a poor reproductive host for $F$. occidentalis $(30,40)$. Reproduction of $F$. occidentalis was poor in this study (Figs. 3 and 4), yet some secondary spread occurred each year as indicated by the significant reductions in late-season TSW incidence by application of the insecticides (Table 1). Development of the two larval instars is about 5 days (31), and the weekly applications of insecticides in the present study should have been sufficient to prevent successful larval development and subsequent secondary spread of TSWV.

In 2000 and 2001, marketable yield was significantly affected by insecticide treatments (Tables 5 and 6). Acibenzolar- $S$ methyl and mulch significantly affected marketable yield in 2000 and 2001, respectively. In the previous studies, it was not possible to determine if increased yields were because of reduced insect populations or because of reduced viruses vectored by the insects, or because of mulch effects on plant growth (13). Further, aluminum foil and aluminum-painted plastic mulches reflect more radiation toward the abaxial sides of leaves, and they emit less long-wave radiation because they are cooler than light-absorbing mulches (15). The mulch effects on plant physiology and growth are not understood, but we expect that positive and negative effects on yield, depending on the circumstances, occur. Fruit from TSWV-infected plants is not marketable (40), yet marketable yields were not increased in these studies only in relation to the reduction in disease incidence (Tables 2 and 3, respectively). When averaged over all treatments in 2000 and 2001, marketable yields from tomatoes grown on UV-reflective versus black mulch were increased 6.9 and $18.0 \%$, respectively, in our study (Tables 5 and 6, respectively). Under commercial conditions in north Florida and south Georgia, growers reported average marketable yields of 63,525 and $54,450 \mathrm{~kg} / \mathrm{ha}$ for tomatoes grown on highly UV-reflective and black mulch, respectively, or a $16.7 \%$ increase (20).

Resistant cultivars may offer the best promise for reducing losses from TSWV, but thus far, market acceptance of these cultivars has been limited. Further, strains of TSWV that have overcome resistance from the single-gene-dominate trait have 
appeared $(1,34)$. An integrated approach is necessary to reduce feeding by thrips and to manage the development of TSWVresistant strains. Integration of UVreflective mulch, acibenzolar- $S$-methyl, and insecticides reduced TSW incidence significantly in 2000 and 2001 compared with incidence in untreated tomatoes grown on black mulch.

The extremely wide range of hosts for both TSWV and its major vector, $F$. occidentalis, is one of the important factors making for a complex pathosystem. Studies addressing weed hosts of thrips, where they may initially acquire TSWV, will contribute to our understanding of this pathosystem (14). However, in the short term, the combination of UV-reflective mulches with acibenzolar-S-methyl and insecticides is providing improved management of this disease under commercial conditions. These tactics are being rapidly adopted by tomato growers in north Florida and south Georgia $(20,23)$.

\section{ACKNOWLEDGMENTS}

We thank Paula King, Jackie Snell, Hank Dankers, Sara Hague, Bhuwan Pradhanang, and Daniel Mailhot for technical assistance. This research was supported with funds provided by the Gadsden County Tomato Growers Association, the Florida Tomato Committee, and the USDA Cooperative State Research, Education, and Extension Service. Contribution from the Florida Agricultural Experiment Station Journal Series R-09911.

\section{LITERATURE CITED}

1. Aramburu, J., and Marti, M. 2003. The occurrence in north-east Spain of a variant of Tomato spotted wilt virus (TSWV) that breaks resistance in tomato (Lycopersicon esculentum) containing the Sw-5 gene. Plant Pathol. 52:407.

2. Bauske, E. M., Zehnder, G. M., Sikora, E. J., and Kemble, J. 1998. Southeastern tomato growers adopt integrated pest management. HortTechnology 8:40-44.

3. Brittlebank, C. C. 1919. Tomato diseases. J. Agric. Victoria 27:213-235.

4. Brown, S. L., and Brown, J. E. 1992. Effect of plastic mulch color and insecticides on thrips populations and damage to tomato. HortTechnology 2:208-210.

5. Chatzivassiliou, E. K., Peters, D., and Katis, N. I. 2002. The efficiency by which Thrips tabaci populations transmit Tomato spotted wilt virus depends on their host preference and reproductive strategy. Phytopathology 92:603609.

6. Chellemi, D. O., Funderburk, J. E., and Hall, D. W. 1994. Seasonal abundance of flowerinhabiting Frankliniella species (Thysanoptera: Thripidae) on wild plant species. Environ. Entomol. 23:337-342.

7. Csinos, A. S., Pappu, H. R., McPherson, R. M., and Stephenson, M. G. 2001. Management of Tomato spotted wilt virus in flue-cured tobacco with acibenzolar- $S$-methyl and imidacloprid. Plant Dis. 85:292-296.

8. Csizinsky, A. A., Schuster, D. J., and Polston, J. E. 1999. Effect of ultraviolet-reflective mulches on tomatoes yield and on the silverleaf whitefly. HortScience 34:911-914.

9. Eger, J. E., Jr., Stavisky, J., and Funderburk, J. E. 1998. Comparative toxicity of spinosad to Frankliniella spp. (Thysanoptera: Thripidae), with notes on a bioassay technique. Fla. Entomol. 81:547-551.

10. Gitaitis, R. D., Dowler, C. C., and Chalfant, R.
B. 1998. Epidemiology of tomato spotted wilt in pepper and tomato in southern Georgia. Plant Dis. 82:752-756.

11. Gorlach, J., Volrath, S., Knauf-Beither, G., Hengy, G., Beckhove, U., Kogel, K.-H., Oostendorp, M., Staub, T., Ward, E., Kessman, H., and Ryals, R. 1996. Benzothiadiazole, a novel class of inducers of systemic acquired resistance, activates gene expression and disease resistance in wheat. Plant Cell 8:629-643.

12. Greenough, D. R., Black, L. L., and Bond, W. P. 1990. Aluminum-surfaced mulch: An approach to the control of tomato spotted wilt virus in solanaceous crops. Plant Dis. 74:805808.

13. Greer, L., and Dole, J. M. 2003. Aluminum foil, aluminum-painted, plastic, and degradable mulches increase yields and decrease insect-vectored viral diseases in vegetables. HortTechnology 13:276-284.

14. Groves, R. L., Walgenbach, J. F., Moyer, J. W., and Kennedy, G. G. 2002. The role of weed hosts and tobacco thrips, Frankliniella fusca, in the epidemiology of Tomato spotted wilt virus. Plant Dis. 86:573-582.

15. Ham, J. M., Kluitenberg, G. J., and Lamont, W. J. 1991. Potential impact of plastic mulches on the aboveground plant environment. Natl. Agric. Plastics Congr. Proc. 23:63-69.

16. Immaraju, J. A., Paine, T. D., Bethke, J. A., Robb, K. L., and Newman, J. P. 1992. Western flower thrips (Thysanoptera:Thripidae) resistance to insecticides in coastal California greenhouses. J. Econ. Entomol. 85:9-14.

17. Kormelink, R., Peters, D., and Goldbach, R. 1998. Tospovirus genus. No. 363 in: Descriptions of Plant Viruses. M. J. Adams, J. F. Antoniw, H. Barker, A. T. Jones, A. F. Muraut, and D. Robinson, eds. AAB Hortic. Res. Inst., Wellesbourne, UK

18. Kring, J. B., and Schuster, D. J. 1992. Management of insects on pepper and tomato with UV-reflective mulch. Fla. Entomol. 75:119129.

19. Louws, F. J., Wilson, M., Campbell, H. L., Cupples, D. A., Jones, J. B., Shoemaker, P. B., Sahin, F., and Miller, S. A. 2001. Field control of bacterial spot and bacterial speck of tomato using a plant activator. Plant Dis. 85:481-488.

20. Mayfield, J. L., and Hudgins, J. 2004. Integrated management of thrips and tomato spotted wilt virus in field-grown fresh market tomatoes. Proc. Fla. State Hortic. Soc. In press.

21. McPherson, R. M., Culbreath, A. K., Stephenson, M. G., and Jones, D. C. 1995. Impact of transplant date and insecticide control practices on the incidence of tomato spotted wilt virus and insect pests of flue-cured tobacco. Tobacco Sci. 39:30-37.

22. McPherson, R. M., Pappu, H. R., Csinos, A. S., and Bertrand, P. F. 1997. Influence of dichloropropene, volunteer peanuts, and thrips control practices on the abundance of insect pests and incidence of tomato spotted wilt in flue-cured tobacco. Tobacco Sci. 41:94-102.

23. Momol, M. T., Olson, S. M., Funderburk, J. E., and Marois, J. J. 2003. Integrated management of tomato spotted wilt on tomato. (Abstr.) Phytopathology 93:S115.

24. Mound, L. A. 1996. The Thysanoptera vector species of Tospovirus. Acta Hortic. 431:298307.

25. Murphy, F. A., Fauquet, C. M., Bishop, D. H. L., Ghabrial, S. A., Jarvis, A. W., Martelli, G. P., Mayo, M. A., and Summers, M. D. 1995. Virus Taxonomy, Sixth Report of the International Committee for Taxonomy of Viruses. Arch. Virol., Suppl. 10:1-586.

26. Nagata, T. 1999. Competence and specificity of thrips in the transmission of tomato spotted wilt virus. Thesis. Wageningen University, Wageningen, Netherlands.

27. Pappu, H. R., Csinos, A. S., McPherson, R. M., Jones, D. C., and Stephenson, M. G. 2000.
Effect of acibenzolar-S-methyl and imidacloprid on suppression of tomato spotted wilt $T o-$ spovirus in flue-cured tobacco. Crop Prot. 19:349-354

28. Puche, H., Berger, R. D., and Funderburk, J. E. 1995. Population dynamics of Frankliniella hrips and progress of tomato spotted wilt virus. Crop Prot. 14:577-583.

29. Ramachandran, S., Funderburk, J., Stavisky, J., and Olson, S. 2001. Population abundance and movement of Frankliniella species and Orius insidiosus in field pepper. Agric. For. Entomol. $3: 1-10$

30. Reitz, S. R. 2002. Seasonal and within plant distribution of Frankliniella thrips (Thysanoptera: Thripidae) in north Florida tomatoes. Fla. Entomol. 85:431-439.

31. Reitz, S. R., Funderburk, J. E., Hansen, E. A Baez, I., Waring, S., and Ramachandran, S. 2002. Interspecific variation in behavior and its role in thrips ecology. Pages 133-140 in Thrips and Tospovirses: Proc. Int. Sympos. Thysanoptera, 7th. R. Marullo and L. A Mound, eds. Australian National Insect Collection, Canberra, Australia.

32. Reitz, S. R., Yearby, E. L., Funderburk, J. E., Stavisky, J., Olson, S. M., and Momol, M. T. 2003. Integrated management tactics for Frankliniella thrips (Thysanoptera: Thripidae) in field-grown pepper. J. Econ. Entomol. 96:1201-1214.

33. Riley, D. G., and Pappu, H. R. 2000. Evaluation of tactics for management of thripsvectored Tomato spotted wilt virus in tomato. Plant Dis. 84:847-852.

34. Rosello, S., Diez, M. J., and Nuez, F. 1998. Genetics of tomato spotted wilt virus resistance coming from Lycopersicon peruvianum. Eur. J. Plant Pathol. 104:499-509.

35. Salguero Navas, V. E., Funderburk, J. E., Beshear, R. J., Olson, S. M., and Mack, T. P. 1991. Seasonal patterns of Franklliniella spp. (Thysanoptera: Thripidae) in tomato flowers. J. Econ. Entomol. 84:1818-1822.

36. Samuel, G., Bald, J. G., and Pitman, H. A. 1930. Investigations on 'spotted wilt' of tomatoes. Commonwealth of Australia, Counc. Sci. Ind. Res. Bull. 44:64.

37. Scott, S. J., McLeod, P. J., Montgomery, F. W., and Hander, C. A. 1989. Influence of reflective mulch on incidence of thrips (Thysanoptera: Thripidae: Phlaeothripidae) in staked tomatoes. J. Entomol. Sci. 24:422-427.

38. Shaner, G., and Finney, R. E. 1977. The effect of nitrogen fertilization on the expression of slow-mildewing resistance in Knox wheat. Phytopathology 67:1051-1056.

39. Sherwood, J. L., German T. L., Whitfield, A E., Moyer, J. W., and Ullman, D. E. 2001. Tomato spotted wilt. Pages 1030-1031 in: Encyclopedia of Plant Pathology, Vol. 2. O. C Maloy and T. D. Murray, eds. John Wiley \& Sons, New York.

40. Staub, T. 2001. Induced disease resistance in crop health management. Online. Plant Health Progress doi:10.1094/PHP-2001-0913-01-PS.

41. Stavisky, J., Funderburk, J., Brodbeck, B. V., Olson, S. M., and Andersen, P. C. 2002. Population dynamics of Frankliniella spp. and tomato spotted wilt incidence as influenced by cultural management tactics in tomato. J. Econ. Entomol. 95:1216-1221

42. Steel, R. G. D., and Torrie, J. H. 1960. Principles and Procedures of Statistics with Special Reference to the Biological Sciences. McGraw-Hill Book Company, New York. p. 481.

43. Sticher, L., Mauch-Mani, B., and Metraux, J. P. 1997. Systemic acquired resistance. Annu. Rev. Phytopathol. 35:235-270.

44. Terry, L. I. 1997. Host selection, communication, and reproductive behavior. Pages 65-118 in: Thrips as Crop Pests. T. Lewis, ed. CAB International, New York. 
45. Thaler, J. S., Karban, R., Ullman, D. E., Boege, K., and Bostock, R. M. 2002. Crosstalk between jasmonate and salicylate plant defense pathways: Effects on several plant parasites. Oecologia 131:227-235.

46. Thaler, J. S., Stout, M. J., Karban, R., and Duffy, S. S. 2001. Jasmonate-mediated induced plant resistance affects community of herbivores. Ecol. Entomol. 26:312-324.

47. U.S. Dep. Agric. 1976. United States Standards for Grades of Fresh Tomato. U.S. Dep. Agric., Agric. Marketing Serv. pp. 1-11.

48. van de Wetering, F., Goldbach, R., and Peters, D. 1996. Tomato spotted wilt tospovirus inges- tion by first instar larvae of Frankliniella occidentalis is a prerequisite for transmission. Phytopathology 86:900-905.

49. Vernon, R. S., and Gillespie, D. R. 1990. Spectral responsiveness of Frankliniella occidentalis (Thysanoptera: Thripidae) determined by trap catches in greenhouses. Environ. Entomol. 19:1229-1241.

50. Vos, J. G. M., Uhan, T. S., and Sutarya, R. 1995. Integrated crop management of hot pepper (Capsicum spp.) under tropical lowland condition: Effects of rice straw and plastic mulches on crop health. Crop Prot. 14:445-452.

51. Webb, S., Tsai, J., and Mitchell, F. 1998. Bio- nomics of Frankliniella bispinosa and its transmission of tomato spotted wilt virus. Pages 67-68 in: Int. Sympos. Tospovirus Thrips Floral Vegetable Crops, 4th.

52. Wijkamp, I., and Peters, D. 1993. Determination of the median latent period of two tospoviruses in Frankliniella occidentalis, using a novel leaf disk assay. Phytopathology 83:986-991.

53. Zhao, G., Liu, W., Brown, J. M., and Knowles, C. O. 1995. Insecticide resistance in field and laboratory strains of western flower thrips (Thysanoptera: Thripidae). J. Econ. Entomol. 88:1164-1170. 